\title{
Population structure of Laurus nobilis L. in Central Italian forests: evidence for its ongoing expansion
}

\author{
Nicola Alessi ${ }^{1,3} \cdot$ Camilla Wellstein $^{1}\left[\right.$ Crancesco $^{-}$Spada $^{2} \cdot$ Stefan Zerbe $^{1}(\mathbb{C}$
}

Received: 10 September 2020 / Accepted: 18 February 2021 / Published online: 11 March 2021

(c) The Author(s) 2021

\begin{abstract}
During the last decades, an ongoing spread of broad-leaved evergreen laurophyllous species has been reported for forests of Southern Europe. Several factors were suggested as the main drivers of the phenomenon, namely global warming, land-use change, evolutionary history, and increase in atmospheric $\mathrm{CO}_{2}$. Among laurophylls, Laurus nobilis $\mathrm{L}$. is considered one of the most prominent from the morphological, evolutionary, and ecological point of view. We studied the population structure of L. nobilis in Central Italy in its natural habitat to investigate its regeneration and potential expansion along with the influence biotic and abiotic factors. To define types of population structures, we collected proportions of six growth classes of $L$. nobilis in 16 sites. We obtained three types of population structure, i.e., (1) stable, (2) dynamic, and (3) regressive. The first two types are the most frequent, suggesting a potential increase of L. nobilis abundance within forests of Central Italy. The regressive population type occurs mainly in sites with heavy ungulate impact. High propagule pressure along with shaded and moist environmental conditions favor L. nobilis regeneration. Accordingly, we found evidence of a recent $L$. nobilis spread in Central Italian forests. We suggest the increase of forest cover and age, due to the abandonment of traditional rural practices, as key factors for the regeneration of this apparently late-successional laurophyll. In conclusion, the recent expansion of $L$. nobilis that we observed in the Italian forest stands can therefore be ascribed to a process of natural recover of a potential niche following land-use change.
\end{abstract}

Keywords Browsing $\cdot$ Evergreen broad-leaved species $\cdot$ Late-successional species $\cdot$ Laurophyllisation $\cdot$ Rooting

\section{Introduction}

Relic European laurophyllous species, such as Laurus nobilis L. (laurel), Rhododendron ponticum L., Prunus lusitanica L., were traditionally studied for their biogeography and evolutionary history, because they are considered remnants of the subtropical forest covering the southern part of Paleo-Europe during the late Tertiary (Axelrod 1975; Mai 1989; Palamarev 1989). Laurophylls are evergreen,

Nicola Alessi

nicola.alessi5@unibo.it

1 Faculty of Science and Technology, Free University of Bozen-Bolzano, Bolzano, Italy

2 Department of Plant Ecology and Evolution, Uppsala University, Uppsala, Sweden

3 Biodiversity and Macroecology Group, Department of Biological, Geological and Environmental Sciences, Alma Mater Studiorum - University of Bologna, Via Irnerio 42, 40126 Bologna, Italy meso-hygromorphic, and late-successional species, today mainly scattered throughout the warm-mesic forests of Southern Europe (Barbero and Quézel 1994; Walter and Breckle 2002). During the last decades, a renewed interest for these species has been stimulated by the spread and invasion, respectively, of several native and alien laurophylls within deciduous forest stands of the Southern Alps-a phenomenon which is called laurophyllisation (Klötzli and Walther 1999). It is well known that laurophylls' ecological niche is in a warm and wet climate (at least 6 warm months and the minimum monthly mean during the year above $0{ }^{\circ} \mathrm{C}$, Box 2015). Because of the laurophylls' preference for a warm climate, the current global warming has been proposed as the main driver of the laurophylls' spread (Carraro et al. 1999; Fujiwara and Box 1999; Walther 2001). However, in more recent studies, the role of the evolutionary history and land-use change have been suggested as key factors of the laurophylls' spread (Alessi et al. 2019; Conedera et al. 2017). Indeed, the great availability of free niches due to a limited post-glacial dispersal (Alessi et al. 2019) 
combined with an increased propagule pressure due to the widespread use of laurophylls in home gardens and parks (Conedera et al. 2017) might favor the expansion of laurophylls more than climate. Moreover, the ongoing increase of the atmospheric $\mathrm{CO}_{2}$ concentrations is favoring broad-leaved evergreen species over deciduous ones because of the competitive advantage given by some physiological characteristic of the evergreen habit, e.g., lower mesophyll diffusion conductance of $\mathrm{CO}_{2}$ (Niinemets et al. 2011).

Among the species involved in the laurophyllisation, $L$. nobilis L. (laurel) is considered one of the most emblematic European native laurophylls (Giacobbe 1939; Barbero and Quézel 1994). Indeed, fossil traces of the genus Laurus confirms its conspicuous role in the Late Tertiary laurophyllous biome (Ferguson 1974; Palamarev 1989). Moreover, the apparently unchanged preference of $L$. nobilis for a warm and humid climate since the Late Pliocene (Rodríguez-Sánchez and Arroyo 2008; Alessi et al. 2018, 2019) makes the species representative for the laurophyllous species stock. According to macro-climatic species distribution models, a northward shift of the laurels' range has been inferred for the end of this century within the global-warming scenario (Rodríguez-Sánchez and Arroyo 2008). It is noteworthy that during the last 2 decades, in several studies describing the species composition of forest communities in Central Italy, a high level of rejuvenation of L. nobilis has been observed (Viciani and Moggi 1997; Bertacchi et al. 2004; Foggi et al. 2006). This evidence suggest expansion dynamics of $L$. nobilis among the Italian populations. However, quantitative studies on $L$. nobilis populations' status based on empirical data are yet missing for the Mediterranean region.

Understanding the dynamic of $L$. nobilis populations is of crucial importance, since the species is a prominent remnant of the once widespread evergreen biomes of Late Neogene Paleo-Europe (Rodríguez-Sánchez and Arroyo 2008). It is plausible that most of its genetic diversity, inherited by a complex biogeographical history, is harbored within populations located in South European refugia (Hampe and Petit 2005; Rodríguez-Sánchez et al. 2009). Since Central Italy has been described as a refuge area for laurophylls (Di Domenico et al. 2012; Alessi et al. 2019), conservation planners should be aware of the possible spread of $L$. nobilis and of its drivers, to assess proper management actions targeted to the ongoing dynamics of the involved native vegetation. Especially, if we consider that, L. nobilis in Italy is able to form community types protected by the Annex I of the European Habitat Directive (92/43/CEE).

Accordingly, we study the population structure and rejuvenation of L. nobilis in Central Italy, to test the hypothesis of local expansion of this tree. Indeed, population structure is a good indicator for the viability and the regeneration performance of a species in a selected environment (Hegland et al.
2001; Brys et al. 2003; Endels et al. 2004). Abundance of seedlings, saplings, and young trees reflects past successful recruitment of a species, hence, its establishment and expansion (Moora et al. 2007) or, conversely, its retreat (Aguraiuja et al. 2008). Furthermore, following the hypothesis that the increase of forest areas during the last decades promotes the spread of laurophylls, we analyzed various abiotic and biotic factors which might influence the tree regeneration. Indeed, by considering light and moisture availability at the ground level, we aim to test the importance of a closed forest canopy for the regeneration a late-successional species as $L$. nobilis (Barbero and Quézel 1994; Alessi et al. 2019). In addition to the constraints of the local environmental conditions, biotic interactions also affect the species spread. Increased propagule pressure has been described as one of the main factors for the laurophylls' spread (Conedera et al. 2017). However, the impact of the recent and substantial growth of populations of wild ungulates in Central Italy, mostly wild boars and fallow deers (Burrascano et al. 2015a, b; Bongi et al. 2017), on L. nobilis regeneration has to be considered.

This study aims to:

1. Assess the status of the L. nobilis population structure in different forest communities of Central Italy;

2. Investigate how abiotic and biotic factors affect $L$. nobilis regeneration and the structure of populations.

\section{Methods}

\subsection{Short species description}

Laurus nobilis (laurel) is an evergreen dioecious tree widespread throughout the Mediterranean region and the Atlantic coasts of Southern Europe (Giacobbe 1939; Filibeck 2006; Rodríguez-Sánchez and Arroyo 2008). It is the only species of the family Lauraceae occurring in Europe, whereas the closely related $L$. azorica is restricted to the Macaronesian Islands (Rodríguez-Sánchez et al. 2009). The genus persisted in Europe throughout the Neogene and the Pleistocene decline (Ferguson 1974; Palamarev 1989; Rodríguez-Sánchez et al. 2009). Compared to the typical Mediterranean sclerophyllous species, L. nobilis shows a higher degree of adaptation to shaded environments and a preference for warm and moist climates (Giacobbe 1939; Alessi et al. 2018). These ecological requirements, shared by most laurophylls, do not seem to have changed during the last 3 Myr (Rodríguez-Sánchez and Arroyo 2008). Nevertheless, L. nobilis occurs also in districts with typical Mediterranean macroclimate, where it escapes the effects of summer drought in sites with persistent soil moisture (Giacobbe 1939; Alessi et al. 2018). A prominent morphological trait that allows the species to survive under adverse conditions 
(i.e., aridity, fires, and stems damages) might be its lignotuber which is an underground organ with high resprouting capacity and high potential for clonal growth. Furthermore, L. nobilis has a high capacity to avoid water stress on leaves developing a low transpiration rate and capacity to quickly recover the water content in the tissues (Lo Gullo and Salleo 1988). Low winter temperatures are also a limiting factor for the species' distribution (Rodríguez-Sánchez and Arroyo 2008; Alessi et al. 2018). It has been shown that the temperatures ranging from -6 to $-16{ }^{\circ} \mathrm{C}$ can produce $50 \%$ of injury to different organs of the tree (Larcher 2000). Since pollen and seed viability in L. nobilis is very low ("recalcitrant" behavior; see Franchi et al. 2011) and an overall impoverished mutualist community of disperses seems to be associated to it (Hampe 2003), the species is apparently not adapted to long-distance dispersal (Pacini et al. 2014). Accordingly, seeds mainly germinate close to the mother tree, also relying upon a short-distance endozoochory of birds (Hampe 2003).

In Italy, L. nobilis occurs as scattered populations in different types of Mediterranean and sub-Mediterranean woodland, where it, only in rare cases, can attain tree habitus or dominates the stand structure (Alessi et al. 2018). At its southernmost range margin, the species is sometimes recorded at the edge of residual forests (Gianguzzi et al. 2010). According to Annex I of the European Habitat Directive (92/43/CEE), these stands are relevant for conservation and protected as Habitat, namely 5230*-Arborescent matorral with Laurus nobilis and 5310-Laurus nobilis thickets.

\subsection{Sampling design and data collection}

We selected representative sites where L. nobilis occurs throughout Central Italy according to its native range (Filibeck 2006). Furthermore, we avoided sites where the species was rare or occasional on the basis of species' cover and frequency provided by a national database (Agrillo et al. 2017). Therefore, 16 sites were selected throughout Central Italy (Fig. 1). On each site, plots containing at least one $L$. nobilis individual (seedling, sapling, or mature tree) were sampled. The number of plots for each site ranged from 2 to 6 , depending on the extension of the $L$. nobilis population directly assessed in the field.

First, counts of L. nobilis individuals divided in 6 growth classes were obtained assessing circular plots of $200 \mathrm{~m}^{2}$. In detail, the growth classes were composed by a mature class and 5 juvenile classes defined as follows: class I, seedlings; class II, saplings $>10-50 \mathrm{~cm}$ and a diameter at breast height $(\mathrm{DBH})<4 \mathrm{~cm}$; class III, saplings $>50-100 \mathrm{~cm}$ and a DBH $<4 \mathrm{~cm}$, class IV, saplings $100-150 \mathrm{~cm}$ and a $\mathrm{DBH}<4 \mathrm{~cm}$; class $\mathrm{V}$, saplings $>150 \mathrm{~cm}$ and a $\mathrm{DBH}<4 \mathrm{~cm}$; mature class, individuals with flowers or a DBH $>4 \mathrm{~cm}$
(Arévalo et al. 1999; Mirschel et al. 2011). While individuals belonging to the mature class were counted within the entire plot, individuals belonging to juvenile classes were counted within 2 circular subplots of $25 \mathrm{~m}^{2}$ established following a systematic sampling design where the two subplots were located, respectively, at the north-west and south-east quadrant of the plot. As a term of comparison, individuals of all occurring woody species belonging to juvenile classes were counted within the two subplots. In total, we sampled 71 plots corresponding to 142 subplots (Online Resource 1).

Second, relevant abiotic and biotic factors for L. nobilis were obtained for each of the sampled plot (Table 1). All the species occurring in the herb $(<1 \mathrm{~m}$ growth height $)$ and shrub layer (1-5 $\mathrm{m}$ ) were recorded as indicators of the environmental conditions at ground level following the nomenclature of Conti et al. (2005). The recorded species were used to evaluate the light and moisture availability in each plot by calculating the unweighted mean of Ellenberg species indicator values for light and moisture according to Pignatti (2005) for the Italian flora. The species table was composed by a total of 136 taxa (Online Resource 2). The level of shading at the ground level was furtherly estimated by the visual assessment of percentage cover of the canopy layer ( $>5 \mathrm{~m}$ growth height). As additional indicator for the moisture, we extracted the topographic wetness index from the Envirem database (Title and Bemmels, 2017). The number of flowering female individuals of L. nobilis within the plots or in the close surrounding (within $15 \mathrm{~m}$ from the center of plots) was recorded to gain information on seed sources, i.e., the propagule pressure. As an indicator for competition among tree species, basal area in square meters per hectare was obtained measuring DBH of mature woody species (Pretzsch and Biber 2005). The abundance of ungulates was assessed at each site using a three-level qualitative scale. We based our qualitative scale on two types of observations, i.e., the visual assessment of both browsing signs on the vegetation and rooting signs on the ground (mostly absent or evident signs) and the visual assessment of ungulates (none, occasional, or frequent). Eventually, we assigned a qualitative value for the frequencies of ungulates to each site, namely almost absent, occasional and abundant (Table 2). We conducted this visual assessment at each site within the area where populations of L. nobilis occurred during 2 days of fieldwork in the daily hours. The fieldwork was carried out in 2015 and 2016.

\subsection{Data analysis}

To group plots according to their population structure, we used the K-means clustering method. It maximizes the between-groups structural dissimilarity and the withingroups structural similarity (Borcard et al. 2011). For this purpose, each plot was defined by the sum of individuals 
Fig. 1 Maps showing a the distribution of $L$. nobilis in Italy obtained from (Filibeck 2006; Agrillo et al. 2017) and b the distribution of the sampled sites in Central Italy. The black dots represent $L$. nobilis occurrences, the dashed square encloses the study area, and the red dots represent the sampled sites (color figure online)
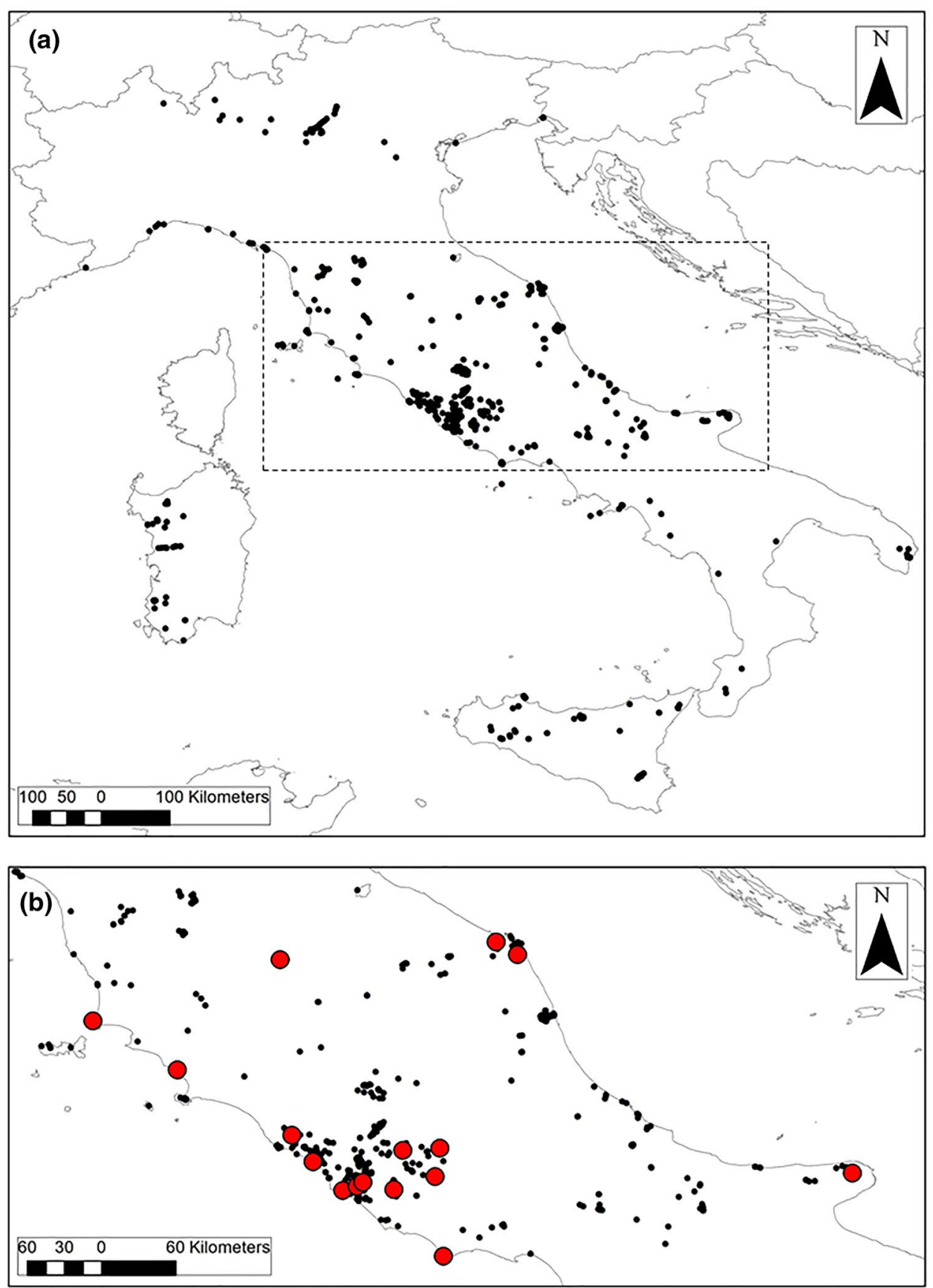

counted in the two subplots. Studies on population structures used proportions of each plant life stage in the clustering (Brys et al. 2003; Kienberg and Becker 2017). Since mature trees were sampled in a different scale from juvenile individuals (the former within plots and the latter within subplots), we clustered population structures using only proportions of juveniles life stages of L. nobilis. However, proportions of L. nobilis mature trees recorded within plots were added a posteriori to gain information on the whole population structure. Due to the high number of zeros in the dataset, we calculated Euclidean distances of Hellinger transformed data between plots (Borcard et al. 2011). The number of groups to interpret was assessed using the interpretability of classification for clustering with 2, 3, and 4 groups.

We classified the structure of each population using the three main types of population structures described in the literature, i.e., the dynamic population, that had a higher proportion of juvenile life stages compared to older stages, the stable population, that had higher proportion of intermediate life stages, such as saplings, compared to juvenile and older stages, and the regressive population, composed mainly by mature life stages and with few individuals of 
Table 1 List of abiotic and biotic factors collected and analyzed, with units and methodology given

\begin{tabular}{lll}
\hline Parameter & Unit & Methods \\
\hline Abiotic factors & & \\
Canopy cover & Percentage & Visual assessment \\
Light indicator & $1-9$ ordinal scale & Unweighted mean of species indicator values (Pignatti 2005) \\
Moisture indicator & $1-12$ ordinal scale & Unweighted mean of species indicator values (Pignatti 2005) \\
Topographic wetness index & - & According to Title and Bemmels (2017) \\
Biotic factors & & \\
Number of $L$ nobilis female individuals & Counts & - \\
Basal area & $\mathrm{m}^{2} / \mathrm{ha}$ & According to Pretzsch and Biber (2005) \\
Rooting and browsing activities & $1-3$ ordinal scale & Visual assessment \\
\hline
\end{tabular}

Table 2 List of the sampled localities and their dominant forest type

\begin{tabular}{|c|c|c|c|c|}
\hline Nature reserve or locality (Nr. plots) & Dominant species & $\begin{array}{l}\text { Evident signs of root- } \\
\text { ing and/or browsing } \\
(0,1)\end{array}$ & $\begin{array}{l}\text { Ungulates } \\
\text { observation }(0 \text {, } \\
1,2)\end{array}$ & Animal frequencies \\
\hline Arsoli (5) & Quercus pubescens, Fraxinus ornus & 0 & 0 & Almost absent \\
\hline SCI of "Selva di Castelfidardo" (4) & Quercus robur, Q. cerris & 0 & 0 & Almost absent \\
\hline Urban park of "Pineta di Castelfusano" (4) & Quercus ilex & 0 & 0 & Almost absent \\
\hline National Park of "Circeo" (4) & Quercus suber, $Q$. pubescens & 1 & 0 & Occasional \\
\hline Botanic garden "Selva di Gallignano" (2) & Quercus cerris & 0 & 0 & Almost absent \\
\hline $\begin{array}{l}\text { Natural monument of "Selva di Genaz- } \\
\text { zano" (4) }\end{array}$ & Quercus cerris & 0 & 0 & Almost absent \\
\hline Regional park of "Castelli Romani" (4) & Castanea sativa & 0 & 0 & Almost absent \\
\hline Natural reserve of Maremma (6) & Quercus ilex, Laurus nobilis & 1 & 2 & Abundant \\
\hline Montecelio (4) & Quercus cerris, Q. ilex & 0 & 0 & Almost absent \\
\hline SCI of "Palo Laziale" (4) & Quercus ilex, $Q$. cerris & 0 & 0 & Almost absent \\
\hline $\begin{array}{l}\text { SCI of "Promontorio di Piombino e Monte } \\
\text { Massoncello" (6) }\end{array}$ & Quercus ilex & 0 & 0 & Almost absent \\
\hline $\begin{array}{l}\text { "Tenuta presidenziale di Castelporziano" } \\
\text { (6039) }\end{array}$ & Quercus ilex, $Q$. cerris & 1 & 2 & Abundant \\
\hline A.N.P.I.L. of "Bosco di Sargiano" (4) & Quercus petraea & 0 & 1 & Occasional \\
\hline State Nature Reserve of "Sfilzi" (6) & Acer campestre, Corylus avellana & 0 & 1 & Occasional \\
\hline $\begin{array}{l}\text { SPA of "Comprensorio Tolfetano-Cerite- } \\
\text { Manziate" }(70,000)\end{array}$ & Quercus ilex & 0 & 0 & Almost absent \\
\hline Natural reserve of "Decima-Malafede" (6) & Quercus suber, $Q$. pubescens & 0 & 0 & Almost absent \\
\hline
\end{tabular}

Each locality is classified according the abundance of ungulates (animal frequencies). Classification of localities was made. The classification is based on a three-level qualitative scale obtained using field observations of browsing/rooting signs (mostly absent or evident signs) and ungulates (none, occasional, or frequent)

younger life stages (Hegland et al. 2001; Brys et al. 2003; Endels et al. 2004; Kienberg and Becker 2017). A summarizing illustration of the three types of the population structures found in literature is reported in Fig. 2.

To assess the impact of grazing and browsing animals on L. nobilis regeneration, we compared the number of juveniles in plots where ungulates were absent or occasional, with those in plots where ungulates were abundant. The non-parametric Kruskal-Wallis test was used to detect significant differences between the two groups of plots because of the non-normality of count data. Due to the big difference between numbers of plots in sites where ungulates were almost absent or occasional (60) and in sites where ungulates were abundant (11), for the Kruskal-Wallis test, we randomly selected only 22 plots from the former group. The test was applied to juveniles and mature individuals of $L$. nobilis and, as a term of comparison, to juveniles of all the other tree species recorded.

Generalized linear mixed models (GLMMs) were used to analyze the effect of biotic and abiotic factors on proportion of $L$. nobilis juveniles for each growth class. The models were built using subplots. We used GLMM, because 
Dynamic population

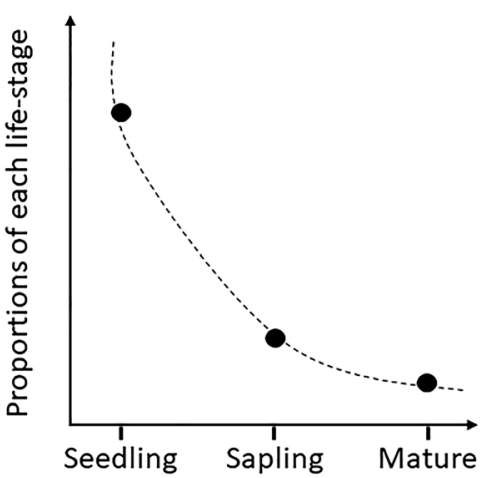

Stable population

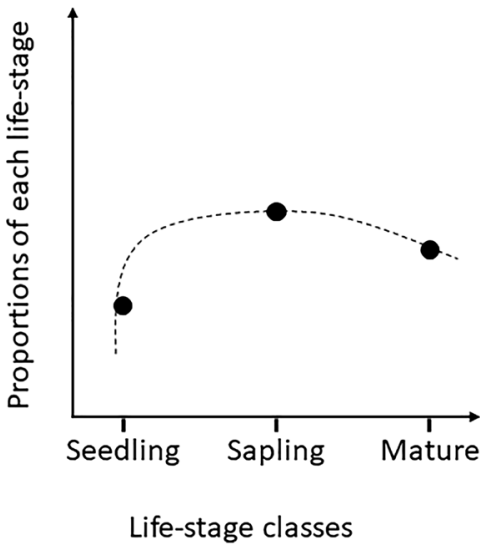

Regressive population

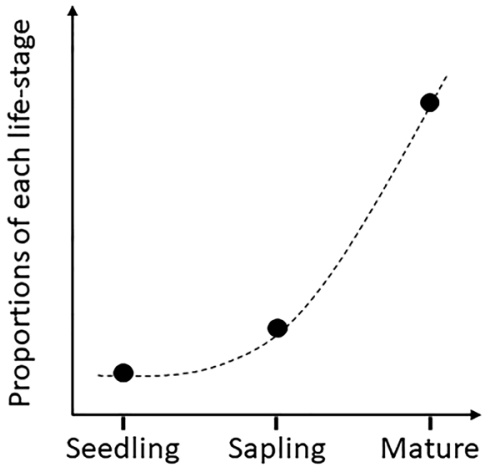

Fig. 2 Main types of population structures according the proportions of individuals in each life stage of the plant. The figure was adapted according to Brys et al. (2003), Endels et al. (2004), Hegland et al. (2001), and Kienberg and Becker (2017)

they allowed to model nested data with a non-normal distribution-as in the count data (Zuur et al. 2009). In our models, we used as random factors subplots nested within plots nested in turn within sites. Namely, the explanatory variables analyzed were: the level of animal disturbance, the numbers of L. nobilis' female close to the plot, basal area, topographic wetness index, tree cover, mean value of Ellenberg's indicators of light, and moisture for the species in the shrub and herb layers. A Spearman correlation was used to identify possible correlations among the selected explanatory variables. The distribution of the count data for L. nobilis juveniles was assumed as "poisson" distribution following Zuur et al. (2009). To detect the best fitting model for the dataset, we used a backward selection based on the significance of terms and the Akaike information criterion (AIC; see Akaike 1973). The "glmer" function of the "Ime4" package (Bates 2005) in R was used to perform the GLMMs.

\section{Results}

K-means clustering of the proportion of L. nobilis juveniles producing 3 groups showed to be the most appropriate solution with, respectively, 23, 16, and 32 plots in each group (Fig. 3). Both the clustering with 2 and 4 groups showed an unbalanced distribution of plots among groups (respectively, 22, 49 and 32, 9, 7, 23). Moreover, the solution with three groups showed a clearly differentiated distribution pattern for the five growth classes (Fig. 3).

The three types of population structure obtained from the clustering of the proportion of L. nobilis juveniles, resembled those quoted in the literature (Fig. 2). We identified the first group as the stable populations, since it showed the highest proportion for middle growth classes (II and V) with a relatively lower proportion of seedlings (class I) and mature trees. The second group was similar to the regressive populations since the proportion of mature trees was higher compared to younger individuals, which were almost absent. However, there was a discrepancy between the high proportion of seedlings in our results and the virtual absence of seedlings in the regressive population as defined in the literature. The fact that the majority of the plots of the second group (63\%) was located in sites with abundant animal disturbance suggested an impact of browsing and rooting on the local regeneration process of $L$. nobilis. The third group was very similar to the dynamic population structure. In this group, we found a higher number of $L$. nobilis individuals from classes I and II, whereas older classes of individuals were only poorly represented.

During the visual assessment of ungulates, we detected the occurrence of wild boars (Sus scrofa L.) and fallow dears (Dama dama L.). Abundant ungulates were only found in two of the sampled sites, while only three sites exhibited occasional occurrence of ungulates (Table 2).

The highest numbers of L. nobilis juveniles per growth classes were recorded in populations where ungulates were almost absent or occasional (Fig. 4a). The Kruskal-Wallis test on the number of L. nobilis juveniles per growth classes between sites where ungulates were almost absent or occasional and sites where ungulates were abundant gave significant results $(p<0.05)$ for the II, III, IV, and V growth classes. The same pattern was observed among juveniles of other arboreal species (Fig. 4b).

The influence of biotic and abiotic factors on the regeneration of $L$. nobilis analyzed by GLMMs was significant for animal disturbance, number of L. nobilis females, tree cover, topographic wetness index, and Ellenberg's indicator for light availability (Table 3). Basal area and the Ellenberg's 


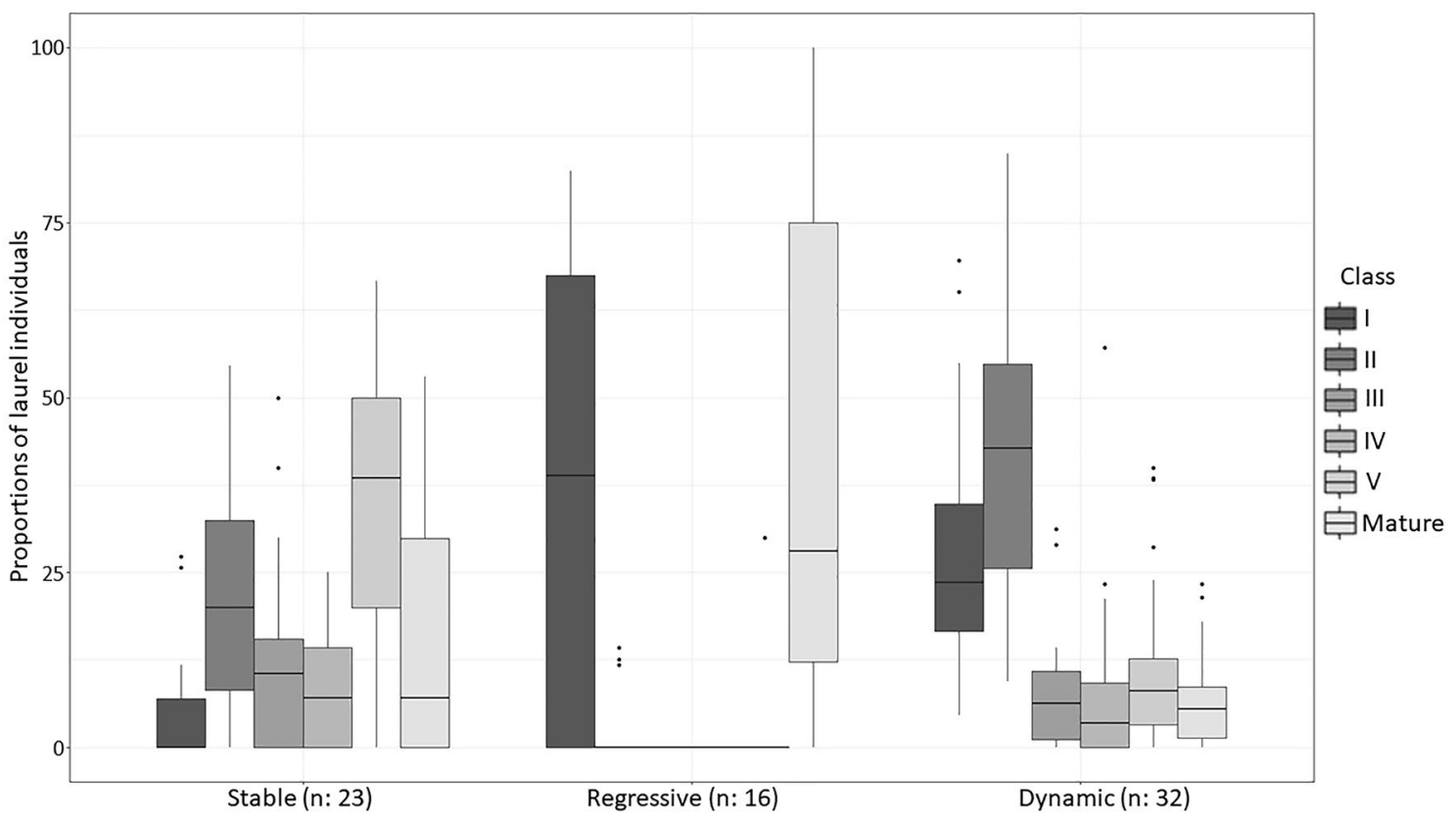

Fig. 3 Proportions of the six growth classes of L. nobilis individuals grouped according to the K-means clustering results. Only proportions of juveniles were used in the k-means, but in the picture are shown also proportions of mature individuals. Numbers of populations for each group are shown at the ordinate axis' labels (a)

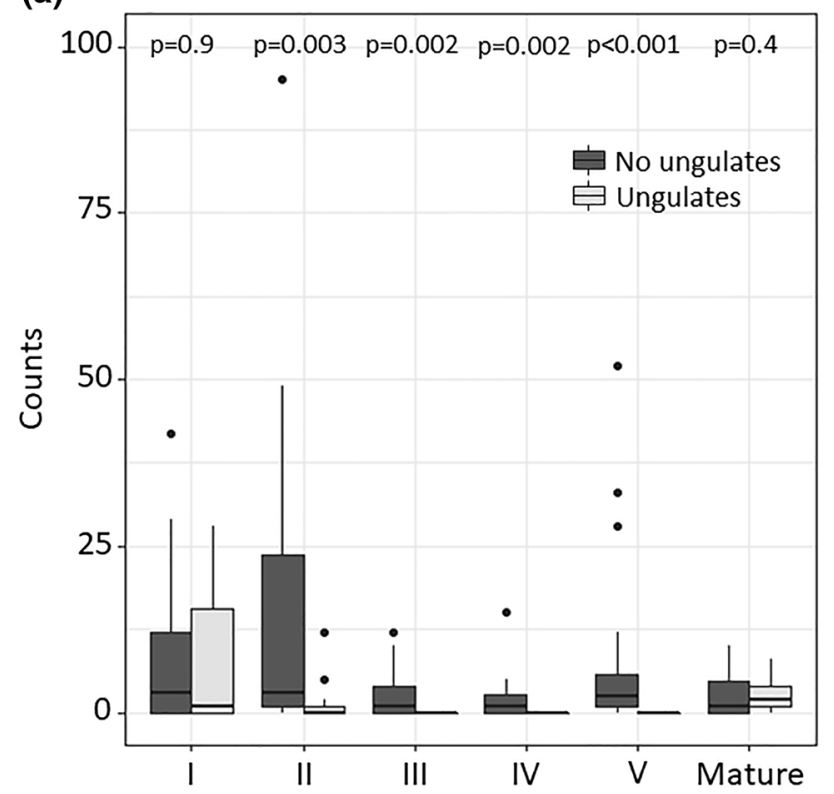

(b)

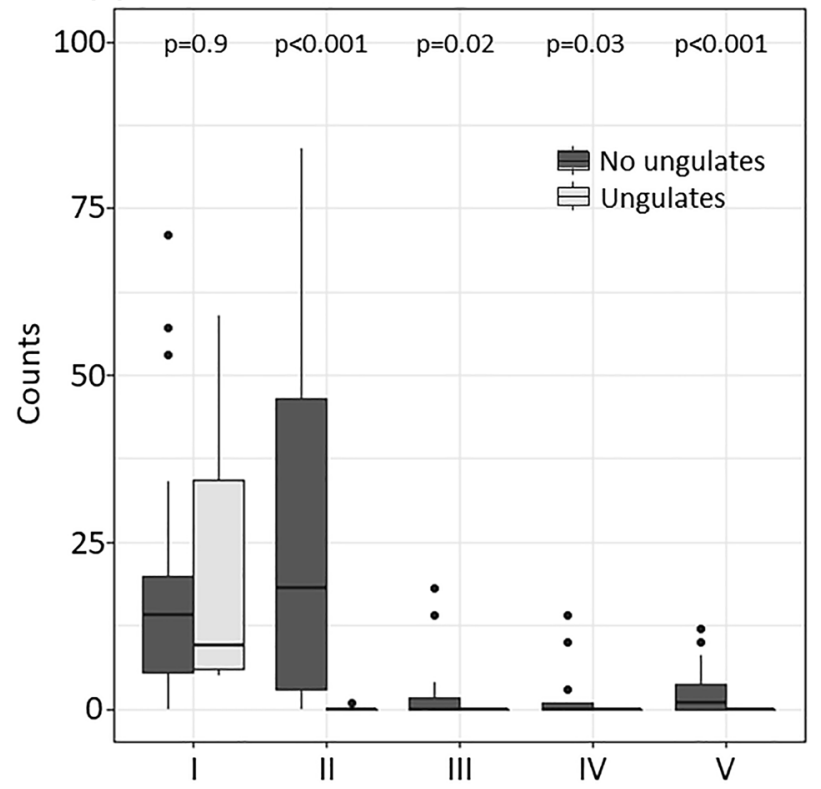

\section{Growth classes}

Fig. 4 Counts of juveniles for each of the growth class in sites with almost absent ungulates (dark gray) and abundant ungulates (light gray). The comparison regards the juveniles and mature trees of $L$. nobilis (a) and juveniles of other tree species (b). $P$ values of the Kruskal-Wallis test for each of the growth class are given 
Table 3 Generalized linear mixed models of the influence of biotic and abiotic factors on the proportion of L. nobilis individuals in different life stages for 16 populations

\begin{tabular}{|c|c|c|c|c|c|}
\hline \multirow[t]{2}{*}{ Factors } & \multicolumn{5}{|l|}{ Growth classes } \\
\hline & I & II & III & IV & $\mathrm{V}$ \\
\hline \multicolumn{6}{|l|}{ Biotic factors } \\
\hline Animal disturbances & n.s & $-0.878 \pm 0.474^{\circ}$ & $-1.139 \pm 0.489^{*}$ & $-1.348 \pm 0.488^{* *}$ & $-1.379 \pm 0.441 * *$ \\
\hline Female & $0.633 \pm 0.283^{*}$ & $0.488 \pm 0.245^{*}$ & $0.790 \pm 0.217 * * *$ & $0.680 \pm 0.225^{* *}$ & n.s \\
\hline \multicolumn{6}{|l|}{ Abiotic factors } \\
\hline Trees cover & n.s & $0.578 \pm 0.248 *$ & n.s & n.s & n.s \\
\hline Light & $-0.710 \pm 0.324 *$ & $\mathrm{n} . \mathrm{s}$ & $-0.794 \pm 0.272 * *$ & $-1.027 \pm 0.298^{* * *}$ & $-0.463 \pm 0.228^{*}$ \\
\hline Topographic wetness index & $0.759 \pm 0.338^{*}$ & $0.668 \pm 0.436$ & $0.785 \pm 0.399 *$ & $0.686 \pm 0.375^{\circ}$ & n.s \\
\hline
\end{tabular}

Estimates, standard errors, and directions of the effects of each variable with significant influence in the best models according to Akaike Information Criteria (AIC) are given. The basal area and the Ellenberg's indicator for moisture were excluded from all the five best models because not significant in any growth class

n.s. non-significant

${ }^{\circ} p<0.1 ; * p<0.05 ; * * p<0.01 ; * * * p<0.001$

indicator for moisture were excluded from all the five best models, since they were not significant. In detail, animal disturbance negatively affected the number of L. nobilis saplings. The number of $L$. nobilis females close to the plots positively affected the number of seedlings and saplings of medium growth classes. Tree cover was positively related to the number of saplings of the II growth class. On the other hand, the Ellenberg's indicator values for light were negatively related to all other growth classes. The topographic wetness index positively affected the number of seedlings and saplings from the II and III classes.

\section{Discussion}

The majority of the investigated L. nobilis populations in Central Italy were classified as dynamic and stable ones, exhibiting a relatively high number of seedlings and saplings, combined with a moderate numbers of aged individuals. This prolific regeneration process confirms that there has been a spread of $L$. nobilis during the past years throughout the study area, as suggested by other studies (RodríguezSánchez and Arroyo 2008; Alessi et al. 2019). Consequently, in the near future, L. nobilis might become an important element of particular forest stands in Central Italy where it showed a stable or dynamic regeneration process in the near future. Among the evaluated biotic and abiotic factors, a high propagule pressure, along with a shaded and moist environment, shows to be factors increasing the success of L. nobilis 'regeneration'. On the other hand, in the few laurel populations characterized by the virtual absence of saplings, abundant seedlings, and aged individuals (classified as regressive), the number of all tree-juveniles resulted to be negatively affected by the occurrence of abundant populations of wild animals.

The high number of dynamic and stable populations of L. nobilis suggests that an increasing amount of individuals in the more aged life stages can be expected, in the future, to enter the structure of many forest communities in Central Italy, including local dominance in environmentally suitable stands. However, a multi-year demographic study including the mortality rate of individuals would be necessary to infer the potential growth rate of the species' populations (Mayberry and Elle 2010). This is especially true for longlived species as trees, where a reverse J-shaped age structure, similar to the dynamic population structure presented in this study, could be indicative for the structure of an oldgrowth forest (Wang et al. 2004; Dang et al. 2010; Chhetri and Cairns 2015). Indeed, in a dynamic or stable population structure, a high mortality rate at the juvenile stages of the propagules could limit the numbers of old individuals, thus, preventing the expansion of L. nobilis. Nevertheless, our conclusion about the potential expansion of L. nobilis in the study area is corroborated by the highly vital regeneration previously reported for several districts in Central Italy (Viciani and Moggi 1997; Foggi et al. 2006), as well in populations in Northern and Southern Italy (Brullo and Guarino 1998; Bacchetta et al. 2007; Gianguzzi et al. 2010; Marino et al. 2014) where we detected populations classified as dynamic or stable. A past vital regeneration combined with the current relatively high numbers of saplings found in these dynamic and stable populations therefore suggest a well-established recruitment process of L. nobilis, both in time and space.

This vital regeneration process is favored by the close proximity of a female individual and by a shaded and moist environment. The occurrence of a female individual for 
a vital regeneration is in line with the fact that events of long-distance dispersal of $L$. nobilis are limited by the short viability of the seeds (Pacini et al. 2014) and by an impoverished community of dispersers (Hampe 2003). However, occasional long-distance events of dispersal could have happened in the course of the biogeographical history of Laurus (Rodríguez-Sánchez et al. 2009). Moreover, the shaded and moist environment needed for a successful recruitment, confirms the late-successional, shade-tolerant and mesohygromorphic character of the species (Giacobbe 1939; Barbero and Quézel 1994; Alessi et al. 2018). This regeneration niche is typical of other species considered relics of the Late Tertiary laurophyllous forest biome, since such micro-environmental conditions of the forest understory resemble the paleo-environment in which their ancestors evolved (Valiente-Banuet et al. 2006).

However, the vital regeneration process of $L$. nobilis might be strongly limited by herbivory—which in our study is mainly represented by browsing and rooting by wild ungulates. Indeed, the regressive populations were found in a few sites where we documented a critical incidence of wild animal populations. The fact that seedlings and mature trees are abundant, while saplings are virtually absent, shows that these sites are environmentally suitable for $L$. nobilis recruitment, but, apparently, animal predation limits the establishment of saplings. In detail, the regressive populations were detected in protected areas in which an active management for the conservation of the wild fauna, based on reintroduction of ungulates, the observed species of ungulates in the areas corresponded to the species more frequently bred in farms and wildlife enclosure. This could generate a substantial growth of animal populations and the subsequent negative impact on the forest understory, as previously suggested (Carnevali et al. 2009; Burrascano et al. 2015a, b; Bongi et al. 2017). However, the majority of the forests surveyed in the present study lack of an active management of natural resources (animals and plants). However, in the majority of the forests surveyed in the present study, being Sites of Community Importance, no active reintroduction of wild ungulates has been performed, thus generating a lighter impact on vegetation dynamic.

In general, the negative effect of wild ungulates on the establishment of L. nobilis saplings mirrors the impact of livestock on forest regeneration reported in other regions of Europe (Smit et al. 2015; López-Sánchez et al. 2016). In this view, the long history of traditional forest grazing in Europe might have limited regeneration of trees in many areas-especially the regeneration of the late-successional ones (Plieninger et al. 2003; Dimopoulos and Bergmeier 2004; Bergmeier et al. 2010). L. nobilis, as late-succesional tree in the study area, is therefore likely to have been heavily affected during a long time. However, the ongoing trend of rural land depopulation and decrease of the traditional forms of environmental impact, leading to an expansion of forests combined with a more undisturbed succession and consequent aging (Tellini-Florenzano 2004; Agnoletti 2007; Falcucci et al. 2007), might favor the shade-tolerant laurophyllous species and enhance their spreading into new areas (Conedera et al. 2017; Alessi et al. 2019). Changes in land use combined with the recent global warming and the increase of $\mathrm{CO}_{2}$ in the athmosphere might even more facilitate the spread of laurophylls (Berger and Walther 2006; Rodríguez-Sánchez and Arroyo 2008; Niinemets et al. 2011).

Forest managers should be aware of the biogeographical and ecological prominence of the native woody laurophylls. Indeed, the recent spread of $L$. nobilis along with other native laurophylls in the southern Alps has been treated as a biological invasion of alien species (Delarze et al. 1999; Klötzli and Walther 1999). However, from a historical point of view, the stock of native laurophylls is actually recolonizing its own potential range in many Mediterranean districts after changes in the paleo-environment and human impact (Barbero and Quézel 1994; RodríguezSánchez and Arroyo 2008; Alessi et al. 2019). The spreading laurophylls might therefore trigger a rearrangement of the composition and structure of certain native forest in Southern Europe in an unpredictable but environmentally consistent way, providing undisturbed succession. The conservation of new emerging laurophyllous-rich forest stands is therefore crucial for the restoration of the natural biodiversity of landscapes since their relictual character in Europe (Walter and Breckle 2002).

Supplementary Information The online version contains supplementary material available at https://doi.org/10.1007/s12210-021-00981-7.

Acknowledgements We acknowledge Marco Massimi, Emiliano Agrillo, Silvia Pioli, and Rita Tonin for help with the field work. We are grateful to the managers of the following natural parks for providing access to the natural reserves and for their support in the field work: SCI of "Selva di Castelfidardo"; National Park of "Circeo"; botanic garden "Selva di Gallignano"; Natural reserve of Maremma; SCI of "Palo Laziale"; "Tenuta presidenziale di Castelporziano"; A.N.P.I.L. of "Bosco di Sargiano"; State Nature Reserve of "Sfilzi".

Author contributions Conceptualization: NA, CW, FS, and SZ. Methodology: NA. Formal analysis and investigation: NA. Writing-original draft preparation: NA. Writing - review and editing: NA, CW, FS, and SZ.

Funding Open access funding provided by Libera Università di Bolzano within the CRUI-CARE Agreement.

Availability of data and materials Data and materials are presented as supplementary material. 


\section{Declarations}

Conflicts of interest The authors declare that they have no conflict of interest.

Ethics approval We confirm that all the research meets the ethical guidelines, including adherence to the legal requirements of the study country. The research did not involve Human Participants and/or Animals.

Consent to participate The author consent to partecipate.

Consent for publication The author consent for publication.

Open Access This article is licensed under a Creative Commons Attribution 4.0 International License, which permits use, sharing, adaptation, distribution and reproduction in any medium or format, as long as you give appropriate credit to the original author(s) and the source, provide a link to the Creative Commons licence, and indicate if changes were made. The images or other third party material in this article are included in the article's Creative Commons licence, unless indicated otherwise in a credit line to the material. If material is not included in the article's Creative Commons licence and your intended use is not permitted by statutory regulation or exceeds the permitted use, you will need to obtain permission directly from the copyright holder. To view a copy of this licence, visit http://creativecommons.org/licenses/by/4.0/.

\section{References}

Agnoletti M (2007) The degradation of traditional landscape in a mountain area of Tuscany during the 19th and 20th centuries: Implications for biodiversity and sustainable management. For Ecol Manag 249:5-17. https://doi.org/10.1016/j.foreco.2007.05.032

Agrillo E, Alessi N, Massimi M et al (2017) Nationwide vegetation plot database-Sapienza University of Rome: state of the art, basic figures and future perspectives. Phytocoenologia 47:221-229. https ://doi.org/10.1127/phyto/2017/0139

Aguraiuja R, Zobel M, Zobel K, Moora M (2008) Conservation of the endemic fern lineage Diellia (Aspleniaceae) on the Hawaiian Islands: can population structure indicate regional dynamics and endangering factors? Folia Geobot 43:3-18. https://doi. org/10.1007/s12224-008-9001-1

Akaike H (1973) Maximum likelihood identification of gaussian autoregressive moving average models. Biometrika 60:255-265

Alessi N, Wellstein C, Spada F, Zerbe S (2018) Phytocoenological approach to the ecology of Laurus nobilis L. in Italy. Rend Fis Acc Lincei 29:343-354. https://doi.org/10.1007/s12210-018-0677-8

Alessi N, Těšitel J, Zerbe S et al (2019) Ancient refugia and presentday habitat suitability of native laurophylls in Italy. J Veg Sci 30:564-574. https://doi.org/10.1111/jvs. 12743

Arévalo JR, Fernández-Palacios MJ, Palmer MW (1999) Tree regeneration and future dynamics of the laurel forest on Tenerife, Canary Islands. J Veg Sci 10:861-868. https://doi.org/10.2307/3237311

Axelrod DI (1975) Evolution and biogeography of Madrean-Tethyan sclerophyll vegetation. Ann Missouri Bot Gard 62:280-334. https ://doi.org/10.2307/2395199

Bacchetta G, Farris E, Fenu G et al (2007) Contributo alla conoscenza dei boschi a Laurus nobilis L. della Sardegna, habitat prioritario ai sensi della Direttiva 92/43/CEE. Fitosociologia 44:239-244

Barbero M, Quézel P (1994) Place, rôle et valeur historique des éléments laurifoliés dans les végétations préforestières et forestières ouest-méditerranéennes. Ann Bot 52:81-133
Bates D (2005) The lme4 Package. R News 5:27-30

Berger S, Walther GR (2006) Distribution of evergreen broad-leaved woody species in Insubria in relation to bedrock and precipitation. Bot Helv 116:65-77. https://doi.org/10.1007/s00035-006-0749-8

Bergmeier E, Petermann J, Schröder E (2010) Geobotanical survey of wood-pasture habitats in Europe: diversity, threats and conservation. Biodivers Conserv 19:2995-3014. https://doi.org/10.1007/ s10531-010-9872-3

Bertacchi A, Sani A, Tomei PE (2004) La vegetazione del monte pisano. Provincia di Pisa Felici Editore, Pisa

Bongi P, Tomaselli M, Petraglia A et al (2017) Wild boar impact on forest regeneration in the northern Apennines. For Ecol Manag 391:230-238. https://doi.org/10.1016/j.foreco.2017.02.028

Borcard D, Gillet F, Legendre P (2011) Numerical ecology with R. Springer, New York

Box EO (2015) Quantitative delimitation of Warm-Temperate deciduous forest areas. In Warm-Temperate deciduous forests around the Northern Hemisphere. In: Box EO, Fujiwara K (eds) WarmTemperate deciduous forests around the Northern Hemisphere. Springer, pp. 277-284.

Brullo S, Guarino R (1998) The forest vegetation from the Garda lake (N Italy). Phytocoenologia 28:319-355

Brys R, Jacquemyn H, Endels P et al (2003) The relationship between reproductive success and demographic structure in remnant populations of Primula veris. Acta Oecol 24:247-253. https://doi.org/10.1016/j.actao.2003.09.002

Burrascano S, Copiz R, Del Vico E et al (2015a) Wild boar rooting intensity determines shifts in understorey composition and functional traits. Community Ecol 16:244-253. https://doi. org/10.1556/168.2015.16.2.12

Burrascano S, Giarrizzo E, Bonacquisti S et al (2015b) Quantifying Sus scrofa rooting effects on the understorey of the deciduous broadleaf forests in Castelporziano Estate (Italy). Rend Fis Acc Lincei 26:317-324. https://doi.org/10.1007/s12210-014-0350-9

Carnevali L, Pedrotti L, Riga F, Toso S (2009) Banca dati ungulati: Status, distribuzione, consistenza, gestione e prelievo venatorio delle popolazioni di Ungulati in Italia. Rapp 2001-2005 Biol Cons Fauna 1-168

Carraro G, Gianoni P, Mossi R (1999) Climatic influence on vegetation changes: a verification on regional scale of the Laurophyllisation. In: Klötzli F, Walther G-R (eds) Conference on recent shifts in vegetation boundaries of deciduous forests, especially due to general global warming. Basel, Boston, Berlin, Birkhauser, pp 69-84

Chhetri PK, Cairns DM (2015) Contemporaary and historic population structure of Abies spectabilis at treeline in Barun Valley, Eastern Nepal Himalaya. J Mountain Sci 12:558-570

Conedera M, Wohlgemuth T, Tanadini M, Pezzatti GB (2017) Drivers of broadleaved evergreen species spread into deciduous forests in the southern Swiss Alps. Reg Environ Chang 18:425-436. https ://doi.org/10.1007/s10113-017-1212-7

Conti F, Abbate G, Alessandrini A, Blasi C (2005) An annotated checklist of the Italian vascular flora. Palombi Editori, Roma

Dang H, Zhang Y, Zhang K et al (2010) Age structure and regeneration of subalpine fir (Abies fargesii) forests across an altitudinal range in the Qinling Mountains, China. For Ecol Manag 259:547-554. https://doi.org/10.1016/j.foreco.2009.11.011

Delarze R, Gonseth Y, Galland P (1999) Lebensräume der Schweiz: Ökologie-Gefährdung-Kennarten. Ott Verlag Thun

Di Domenico F, Lucchese F, Magri D (2012) Buxus in Europe: late quaternary dynamics and modern vulnerability. Perspect Plant Ecol Evol Syst 14:354-362. https://doi.org/10.1016/j.ppees .2012 .07 .001

Dimopoulos P, Bergmeier E (2004) Wood pasture in an ancient submediterranean oak forest (Peloponnese, Greece). Ecol Mediterr 30:137-146 
Endels P, Jacquemyn H, Brys R, Hermy M (2004) Impact of management and habitat on demographic traits of Primula vulgaris in an agricultural landscape. Appl Veg Sci 7:171-182. https://doi. org/10.1111/j.1654-109X.2004.tb00608.x

Falcucci A, Maiorano L, Boitani L (2007) Changes in land-use/landcover patterns in Italy and their implications for biodiversity conservation. Landsc Ecol 22:617-631. https://doi.org/10.1007/s1098 0-006-9056-4

Ferguson DK (1974) On the taxonomy of recent and fossil species of Laurus (Lauraceae). Bot J Linn Soc 68:51-72

Filibeck G (2006) Notes on the distribution of Laurus nobilis L. (Lauraceae) in Italy. Webbia 61:45-56. https://doi.org/10.1080/00837 792.2006.10670794

Foggi B, Chegia B, Viciani D (2006) Contributo alla conoscenza della vegetazione del promontorio di piombino (Livorno-Toscana). Parlatorea VIII:121-139

Franchi GG, Piotto B, Nepi M et al (2011) Pollen and seed desiccation tolerance in relation to degree of developmental arrest, dispersal, and survival. J Exp Bot 62:5267-5281. https://doi.org/10.1093/ $\mathrm{jxb} / \mathrm{err} 154$

Fujiwara K, Box EO (1999) Evergreen broad-leaved forests in Japan and Eastern North America: vegetation shift under climatic warming. In: Klötzli F, Walther G-R (eds) Conference on recent shifts in vegetation boundaries of deciduous forests, especially due to general global warming. Basel, Boston, Berlin, Birkhauser, pp 273-300

Giacobbe A (1939) Ricerche geografiche ed ecologiche sul Laurus nobilis L. Arch Bot 15:33-82

Gianguzzi L, D’Amico A, Romani S (2010) Phytosociological remarks on residual woodlands of Laurus nobilis in Sicily. Lazaroa 31:6784. https://doi.org/10.5209/rev

Hampe A (2003) Frugivory in european laurel: how extinct seed dispersers have been substituted: capsule extinction of ancient frugivores during the quaternary has led to a depauperated seed disperser community for Laurus nobilis and a tight mutualism between the plant a. Bird Study 50:280-284. https://doi. org/10.1080/00063650309461320

Hampe A, Petit RJ (2005) Conserving biodiversity under climate change: the rear edge matters. Ecol Lett 8:461-467. https://doi. org/10.1111/j.1461-0248.2005.00739.x

Hegland SJ, Van Leeuwen M, Oostermeijer JGB (2001) Population structure of Salvia pratensis in relation to vegetation and management of Dutch dry floodplain grasslands. J Appl Ecol 38:1277-1289

Kienberg O, Becker T (2017) Differences in population structure require habitat-specific conservation strategies in the threatened steppe grassland plant Astragalus exscapus. Biol Conserv 211:5666. https://doi.org/10.1016/j.biocon.2017.05.002

Klötzli F, Walther G-R (1999) Recent vegetation shifts in Switzerland. In: Klötzli F, Walther GR (eds) Conference on recent shifts in vegetation boundaries of deciduous forests, especially due to general global warming. Basel, Boston, Berlin, Birkhauser, pp 15-29

Larcher W (2000) Temperature stress and survival ability of Mediterranean sclerophyllous plants. Plant Biosyst 134:279-295. https:// doi.org/10.1080/11263500012331350455

Lo Gullo MA, Salleo S (1988) Different strategies of drought resistance in three Mediterranean sclerophyllous trees growing in the same environmental conditions. New Phytol 108:267-276. https://doi. org/10.1111/j.1469-8137.1988.tb04162.x

López-Sánchez A, Perea R, Dirzo R, Roig S (2016) Livestock vs. wild ungulate management in the conservation of Mediterranean dehesas: implications for oak regeneration. For Ecol Manag 362:99_ 106. https://doi.org/10.1016/j.foreco.2015.12.002

Mai DH (1989) Development and regional differentiation of the European vegetation during the Tertiary. Plant Syst Evol 162:79-91. https://doi.org/10.1007/BF00936911
Marino P, Castiglia G, Bazan G et al (2014) Tertiary relict laurophyll vegetation in the Madonie mountains (Sicily). Acta Bot Gall 161:47-61. https://doi.org/10.1080/12538078.2013.870047

Mayberry RJ, Elle E (2010) Conservation of a rare plant requires different methods in different habitats: demographic lessons from Actaea elata. Oecologia 164:1121-1130. https://doi.org/10.1007/ s00442-010-1809-8

Mirschel F, Zerbe S, Jansen F (2011) Driving factors for natural tree rejuvenation in anthropogenic pine (Pinus sylvestris L.) forests of NE Germany. For Ecol Manag 261:683-694. https://doi. org/10.1016/j.foreco.2010.11.025

Moora M, Kose M, Jõgar Ü (2007) Optimal management of the rare Gladiolus imbricatus in Estonian coastal meadows indicated by its population structure. Appl Veg Sci 10:161-168. https://doi. org/10.1111/j.1654-109X.2007.tb00514.x

Niinemets Ü, Flexas J, Peñuelas J (2011) Evergreens favored by higher responsiveness to increased $\mathrm{CO}_{2}$. Trends Ecol Evol 26:136-142. https://doi.org/10.1016/j.tree.2010.12.012

Pacini E, Sciannandrone N, Nepi M (2014) Floral biology of the dioecious species Laurus nobilis L. (Lauraceae). Flora Morphol Distrib Funct Ecol Plants 209:153-163. https://doi.org/10.1016/j.flora .2014 .02 .001

Palamarev E (1989) Paleobotanical evidences of the Tertiary history and origin of the Mediterranean sclerophyll dendroflora. Plant Syst Evol 162:93-107. https://doi.org/10.1007/BF00936912

Pignatti S (2005) Valori di bioindicazione delle piante vascolari della flora d'Italia. Braun-Blanquetia 39:3-97

Plieninger T, Pulido FJ, Konold W (2003) Effects of land-use history on size structure of holm oak stands in Spanish dehesas: implications for conservation and restoration. Environ Conserv 30:61-70. https://doi.org/10.1017/S0376892903000055

Pretzsch H, Biber P (2005) A re-evaluation of Reineke's rule and stand density index. For Sci 51:304-320. https://doi.org/10.1093/fores tscience/51.4.304

Rodríguez-Sánchez F, Arroyo J (2008) Reconstructing the demise of Tethyan plants: climate-driven range dynamics of Laurus since the Pliocene. Glob Ecol Biogeogr 17:685-695. https://doi.org/10 $.1111 / \mathrm{j} .1466-8238.2008 .00410 . x$

Rodríguez-Sánchez F, Guzmán B, Valido A et al (2009) Late Neogene history of the laurel tree (Laurus L., Lauraceae) based on phylogeographical analyses of Mediterranean and Macaronesian populations. J Biogeogr 36:1270-1281. https://doi.org/10.111 1/j.1365-2699.2009.02091.x

Smit C, Ruifrok JL, van Klink R, Olff H (2015) Rewilding with large herbivores: the importance of grazing refuges for sapling establishment and wood-pasture formation. Biol Conserv 182:134-142. https://doi.org/10.1016/j.biocon.2014.11.047

Tellini-Florenzano G (2004) Birds as indicators of recent environmental changes in the apennines (foreste casentinesi national park, central italy). Ital J Zool 71:317-324. https://doi.org/10.1080/11250 000409356589

Title PO, Bemmels JB (2017) ENVIREM: an expanded set of bioclimatic and topographic variables increases flexibility and improves performance of ecological niche modeling. Ecography. https://doi. org/10.1111/ecog.02880

Valiente-Banuet A, Rumebe AV, Verdú M, Callaway RM (2006) Modern Quaternary plant lineages promote diversity through facilitation of ancient Tertiary lineages. Proc Natl Acad Sci U S A 103:16812-16817. https://doi.org/10.1073/pnas.0604933103

Viciani D, Moggi G (1997) Ricerche su alcuni popolamenti di rovere (Quercus petraea (Matt.) Liebl.) in Toscana (Italia centrale). Webbia 51:237-249. https://doi.org/10.1080/00837792.1997.10670 622

Walter H, Breckle S-W (2002) Walter's vegetation of the earth: the ecological systems of the geo-biosphere, 4 th edn. Springer, Berlin 
Walther G-R (2001) Laurophyllisation-a sign of a changing climate? Springer, Netherlands

Wang T, Liang Y, Ren H et al (2004) Age structure of Picea schrenkiana forest along an altitudinal gradient in the central Tianshan Mountains, northwestern China. For Ecol Manag 196:267-274. https://doi.org/10.1016/j.foreco.2004.02.063

Zuur AF, Ieno EN, Walker NJ et al (2009) Mixed effects models and extensions in ecology with R. Springer, New York
Publisher's Note Springer Nature remains neutral with regard to jurisdictional claims in published maps and institutional affiliations. 